\title{
Return Intentions of Malaysia’s Diaspora: The Push and Pull Factors
}

\author{
Quah Chun Hoo \\ Vinayaka Missions International University College \\ 12000 Butterworth, Penang, Malaysia \\ E-mail: quah@vmiuc.edu.my
}

Siti Rohaida M. Zainal (Corresponding author)

School of Management, Universiti Sains Malaysia Minden

11800 Penang, Malaysia

E-mail: siti_rohaida@usm.my

Guok Eng Chai

GEC Management Consultant, 55100 Kuala Lumpur, Malaysia

E-mail: gecmgmt@yahoo.com

Received: April 23, 2014 Accepted: June 20, 2014 Published: June 24, 2014

doi:10.5296/csbm.v1i1.5863～URL: http://dx.doi.org/10.5296/csbm.v1i1.5863

\begin{abstract}
Despite the huge allocation on funds and attention channeled towards solving the brain drain issue by the Malaysian government, this issue is still far from being resolved. Agencies such as Ministry of Science, Technology and Innovation (MOSTI), Malaysian Development Corporation (MDC) and others have been established to try to lure back our top talents from abroad. MOSTI launched its first brain gain programme in 1995 till 2000, which successfully attracted 94 scientists, of whom only one remains in Malaysia. The second brain gain scheme which was implemented from 2001 to 2004 was intended to attract 5000 talents a year. Unfortunately, only 200 took advantage of the offer. Then, to better coordinate the plan, Talent Corporation Malaysia Berhad was established under the Prime Minister's Department with the objective of wooing foreign talent and overcoming the barriers for them to settle
\end{abstract}


down in Malaysia, among others (Starbizweek, 2011b). Unfortunately, the reception to these initiatives is far from encouraging. Even though the study on brain drain is not new among researchers; in Malaysia, empirical studies on this issue is still limited. Drawing on the push and pull factors identified by previous researchers, this paper attempts to conceptualize which of these factors have the greatest potential of influencing the return intentions of Malaysia's top talents working abroad. Proposing two propositions, this conceptual paper then analyzes related articles on the facts about brain drain. The implications of this paper are discussed from two perspectives namely are from the company's as well as from the country's perspectives. In conclusion, this paper highlights the push and the pull factors influencing brain drain phenomenon in Malaysia.

Keywords: Brain drain, Brain gain, Diaspora networks, Push and pull factors, Talent Corporation, Returning Experts Programme (REP) 


\section{Introduction}

Brain gain, the converse of brain drain, is becoming increasingly critical for the Third World or less developed countries to enhance their competitiveness and economic growth in the wake of globalization and heightened international competition. Prior to the globalization era which started after the fall of Berlin walls in 1989, brain drain or migration of educated and skilled people from the less developed economies (the home countries) to the developed or industrialized economies (the host countries) such as United States of America (USA) and United Kingdom (UK) had been viewed as a very serious problem which has negative impact on the less developed nations.

Countries like India and China have long experienced brain drain and their governments have implemented effective policy measures to woo their talents back to their homelands. These countries had been successful in attracting the return of their expatriates (Ziguras and Law, 2006), so much so that they have reversed the situation from brain drain to brain gain. This is particularly true in the case of India whereby Information Technology skilled professionals who worked in USA had returned back to benefit India economically (Hunger, 2002).

The concept of brain gain was popularized in the 1990s by authors like Mountford, 1997; Stark et al., 1997; and Straubhaar and Wolburg, 1999. The basic idea of the brain gain hypothesis is that intellectual and technical elites from Third World who immigrated to an industrialized country represent a potential resource for the socioeconomic development of their home country (Hunger, 2002). In the case of Malaysia, "brain drain - the migration of talent across borders has long been a subject of debate and controversy” (Starbizweek, 2011a). The Malaysian intellectual capital, as Stewart (2000) maintained, is walking out of the door or airport, as the case may be, presumably because the work environment among others, is not stimulating and fulfilling (Strempel, 2003). Malaysia is currently facing a problem to strengthen its human capacity building due to the issue of brain drain. It is commonly acknowledged that "brain drain" migration always involve a migration of elites from a developing country to an industrialized country. Hence, a "brain gain” programme is supposed to reverse this trend through a remigration of elites, who have acquired invaluable skills and experiences living in an industrialized country back to the home country (Hunger, 2002).

The Malaysian diaspora is estimated to be about 1 million worldwide in 2010 and it has increased four-fold over the last 30 years and is geographically concentrated and ethnically skewed (Starbizweek, 2011a). It is the non-bumiputras that constitute the bulk of the diaspora compared to the bumiputras (Starbizweek, 2011a). In recent years, talented bumiputras too have left to join the one million Malaysian diaspora (Starbizweek, 2011c). Approximately 90 percent of the Malaysian diaspora are in Singapore with the remaining residing in Australia, Brunei, UK and US (Starbizweek, 2011a; Starbizweek, 2011d). Furthermore, of the estimated 1 million Malaysian diaspora, about 844,000 are aged 25 years and above. Among this age group approximately 455,000 are highly skilled professionals who have completed tertiary education (Foo, 2011). Dr. Wilson Tay, CEO of the Malaysian Institute of Management, indicated that "about 100,000 Malaysians are emigrating overseas annually and the number is 
still increasing. This is especially acute in the highly skilled areas of advanced financial markets, telecommunication, biotechnology, material science and nanotechnology with increased outbound migration of surgeons, doctors and highly specialized educationists and professionals” (The Edge, 2008).

The Malaysian government has implemented many strategies and plans, involving huge capital outlay, under various government and non-government related agencies such as Ministry of Science, Technology and Innovation (MOSTI), Malaysian Development Corporation (MDC) and others to try to lure back our top talents from abroad. MOSTI launched its first brain gain programme in 1995 till 2000, which successfully attracted 94 scientists, of whom only one remains in Malaysia. The second brain gain scheme which was implemented from 2001 to 2004 was intended to attract 5000 talents a year. Unfortunately, only 200 took advantage of the offer. Lim (2004) mentioned that "the current scheme, run by the Ministry of Human Resources, prioritizes the return of Malaysians with expertise in information and communication technology, microelectronics, biotechnology, advanced manufacturing, advanced materials, pharmaceuticals, aerospace and energy". The serious commitment of the Malaysian government towards ensuring the success of the brain gain programmes is reflected in the $10^{\text {th }}$ Malaysia Plan (2011 to 2015) which is based on the New Economic Model that incorporates the Economic Transformation Programme and Government Transformation Programme to develop Malaysia into a high-income and developed nation by the year 2020. As a result, Talent Corporation Malaysia Berhad was established under the Prime Minister's Department with the objective of wooing foreign talent and overcoming the barriers for them to settle down in Malaysia, among others (Starbizweek, 2011b).

There are many "pull” and "push" factors why Malaysians are leaving the country. Ziguras and Law (2006) mentioned that many Malaysian Chinese and Indians which constitute the non-bumiputras have left Malaysia because of limited opportunities of employment in the civil service and public educational institutions including universities. However, Zul Baharom, General Council Member of the Malaysian Institute of Management contends that people left not only because of issues of salaries, business opportunities and comfortable living, but due to more serious issues like a sense of frustration with the rigid bureaucratic and unresponsive government machinery, controls on personal freedom, racial antagonism and religious divide (Starbizweek, 2011e). Johan Mahmood Merican, head of the Talent Corporation Malaysia Berhad stated that people left Malaysia for various reasons such as higher pay, professional development, public transport and education for their children (Starbizweek, 2011g). World Bank’s Philip Schellekens stated that "the fundamental issues or underlying factors why people leave relate to economic incentives which can be captured under the umbrella of low productivity and social disincentives which reflect discontentment among the non-bumiputras with Malaysia’s inclusiveness policies” (Starbizweek, 2011a). The drivers of brain drain in Malaysia in descending order based on a survey conducted by World Bank are career prospects, social injustice, compensation, study and stay on, safety and security, politics, study and return, and livability (Source: World Bank: Malaysia Economic Monitor-Brain Drain cited in Starbizweek, 2011d). 
On the other hand, there is the question of why Malaysians working abroad are reluctant to return home. Among the issues cited by local headhunters and human resource consulting experts encompass unfair treatment where promotions and seniority are concerned and the unchallenging and unfulfilling environment in terms of working with non-talented colleagues in Malaysia (New Straits Times, 2010).

Needless to say, if the problem of brain drain in Malaysia is left unchecked, it will seriously jeopardize the effectiveness of the Economic Transformation Programme to transform Malaysia into a high-income and developed economy by 2020. Since little empirical research has been carried out on the impact of "pull" and "push" factors of brain gain in Malaysia, the real reason for Malaysia’s top talents’ reluctance to return remains unresolved.

\section{Definition and Concept of Brain Gain}

According to Glytsos (2010), brain gain represents the modern view of brain drain. Basically, the traditional view of brain drain states that migration of skilled professionals to a host country has a negative impact on the socio-economic development of the home country. Whilst, the modern view of brain drain (i.e., brain gain) states the reverse i.e. migration of skilled professionals to a host country has a positive effect on the socio-economic development of the home country. Hunger (2002) posits that "intellectual and technical elites from Third World who immigrated to an industrialized country represent a potential source for the socio-economic development of their home country”. Hunger's (2002) brain gain hypothesis is grounded on two fundamental assumptions: (i) that "the Third World elites that emigrated to an industrialized country are able to play an important role in the development process of their home country through return migration and/or transnational networks" and (ii) that "it is possible to give the emigrated elites of a developing country sufficient incentives to emigrate even if they have already been living abroad for a long time and have not yet build up any productive contact to their country of origin”. According to Hunger (2002) "a return of emigrated elites and/or building of transnational networks is likely if the pro-arguments for a return to the home country outweighs the counter-arguments for a stay in the industrialized country and the migrant therefore benefits from remigration; once remigration has started and networks have been established, further remigrations are likely to follow”.

Tung and Lazarova (2006) mentioned that return migration or remigration of highly skilled diaspora, regardless whether it is temporary or permanent in nature, is crucial to a nation's economic transformation. This view is shared by Malhotra (2009), who reported that the global policy shift from the emphasis on brain drain policy to brain gain policy as adopted by less developed economies had resulted in an increasing number of these economies coming to appreciate their skilled diaspora as an asset for attaining economic growth and development. He further stressed that there are two alternative strategies to achieve the brain gain policy: (i) the return option strategy which will enable the achievement of brain gain policy through the return of migrants to their home country. The return option strategy was initially pursued in 1970s and was increasingly dominant in 1980s and 1990s; and (ii) the diaspora option strategy or networks of experts (Gupta 
\& Tyagi, 2011) which unlike the return option strategy, is more recent and it is not aimed at the physical repatriation of diaspora working abroad. Instead, its purpose is to mobilize and utilize the diaspora's resources for the country of origin's socio-economic development (Malhotra, 2009). To date, many countries such as India, Singapore, South Korea, Taiwan, and Malaysia have adopted the return option strategy to lure back their skilled and professional diaspora. In fact, these countries (except for Malaysia) have been successful in luring back their skilled and professional diaspora (Malhotra, 2009). For instance, Chacko (2007) reported that the return of Indian-origin skilled workers on the cities of Bangalore and Hyderabad has accelerated India's socio-economic development.

As for the diaspora option, Malhotra (2009) mentioned that the Colombian government pursues such an option by mobilizing their overseas diaspora and their connection to scientific, technological and cultural programmes in Colombia. Similarly, China has adopted the diaspora option policy in 2001 to encourage oversea mainlanders to contribute to China's modernization, even if they reside abroad (Zweig et al., 2008). Whilst the brain gain strategy in terms of both return option and diaspora option have their respective strengths and weaknesses, the success of these two options depends heavily on the internal dynamics of the country of origin as well as whether certain root causes resulting in the initial skilled migration have been sufficiently addressed (Malhotra, 2009). These root causes or issues contributing to the initial skilled migration are usually referred to as the "pull and push factors" of brain drain or migration. In short, the new economics of brain drain state that "the outflow of educated migrants (and the possibility of own future migration in particular) can lead to a net increase in the origin country's stock of human capital” (Batista et al., 2011).

\section{Discussion on the Pull and Push Factors}

This section provides a detail discussion on previous literatures on the pull and push factors on brain drain. Since the research on brain drain is limited in the local context, reviews are made based on the international views.

Portes (1976) stressed that "consideration must be given to domestic factors such as economic activity, institutions, political stability, rights and freedoms and the rule of law, as well as the microstructure of relationships, influences and interactions that affect individual decisions and choices" in explaining "the global flow of brain drain between developed and developing countries". Hunger (2002) pointed out that "in brain drain research the emigration of Third World elites is explained with an overweight of incentives for a life in an industrialized country and/or negative conditions in the developing country”. This view is shared by Ho and Tyson (2011) who stated that "push and pull factors are arguably derived from dissatisfaction with one's present location and (mis) perceptions of golden opportunities and affluence elsewhere”. Recent literature has identified various classic push and pull factors of brain drain. These include generic push and pull factors that apply to all migrants or diaspora as well as specific push and pull factors that apply to a particular group or category of diaspora. For instance, highly skilled professional diaspora such as scientists and researchers. 


\subsection{Pull Factors}

Lowell and Findlay (2001) mentioned that better wages and employment conditions, better information, recruitment and cheaper transportation are pull factors which attracted skilled migrants to look for jobs and opportunities in developed countries. Tansel and Gungor (2003) focused on the pull factors such as: high income, better career opportunities, better work environment, and more job openings for a specific profile, better social and cultural environment and proximity to important research and innovation centers as factors influencing the Turkish students' return intentions. Zweig et al. (2008) cited higher remuneration, better living conditions, more stable political systems and more comfortable lifestyles as pull factors that attracted talented people in developing countries who have studied abroad or educated in country of origin to migrate to rich countries.

Kurka et al. (2008) identified: career opportunities abroad, a one-time job opportunities abroad, the advantages of higher income and other benefits abroad, new experiences and adventure, work with best scientists at most prestigious institutions, top research conditions and infrastructure, different working environment and atmosphere, desire to see new place and experience new culture as well as to improve foreign language skills as the pull factors of brain drain of academics and researchers in Austria. Martin and Zurcher (2008) highlighted labor recruitment and family unification (i.e. husbands and wives join spouses, children join parents) as pull factors of brain drain.

Ravendran (2008) reported that Malaysians migrated to work in the United Kingdom and Australia due to pull factors such as: better pay packets, better work life balance and better quality of life. In another study on plugging the brain drain in Malaysia, Wong (2010) had identified job prospects as an important pull factor of brain drain of Malaysian students studying overseas.

Furthermore, Parkins (2011) cited ease and availability of information about opportunities outside Jamaica as pull factor of brain drain in Jamaica. She mentioned that "recruiters from various agencies in the United Kingdom, the United States and Canada advertised various recruitment fairs which offer better working conditions and salary scales than what one obtains in Jamaica”. Javed (2011) mentioned that disparities in working conditions between developed and less developed nations tend to "pull” professionals towards developed countries. He added that young people are "pulled" to rich countries and stay there permanently because of individual freedom, general peace and tranquility in urban and rural areas, high standard of living as well as rule of law and justice. He further added that professionals such as engineers, doctors and para medical personnel and scientists are attracted to western countries that emphasize democratic norms, freedom of expression and low crime environment.

Iravani (2011) contends that emigration of high quality manpower from less developed nations to developed nations are due to pull factors which encompass higher standard of living as well as better research and working opportunities which will enable these migrants to excel. Lastly, the online survey on drivers of brain drain in Malaysia conducted by Foo 
(2011) highlighted two very important pull factors of Malaysian brain drain, namely: better career prospects overseas and more attractive salary/benefits overseas.

Based on the discussion the following proposition is proposed:

P1: The pull factors will affect the level of intention among local Malaysia talents to migrate to other countries.

\subsection{Push Factors}

Sako (2002) in his discussion on the circumstances that shape scientists migration decisions in Africa had identified the following push factors: large disparities in university wages, lack of complementary sector coordination, environmental risk, armed conflict, public mismanagement and corruption, frequent economic downturn as well as tribalism. Tansel and Gungor (2003) adopted the standard push and pull factors of brain drain as factors influencing return intentions of Turkish students. The push factors comprise: low income, lack of career opportunities, unconducive work environment, limited job openings for a specific profile, unconducive social and cultural environment, non-proximity to important research and innovation centers, lack of financial resources to start own company, bureaucracy and inefficiency, political pressure, lack of social security, and economic instability and uncertainty. Nurse (2004) mentioned that economic decline, widening inequality, increasing poverty social displacement, crime and political crises have been the main drivers or push factors of emigration in Americas.

Ziguras and Law (2006) cited limited opportunities for employment in the civil service and public educational institutions including universities as a push factor of brain drain that motivated Malaysian Chinese and Indians (non-bumipuras) to leave the country. Martin and Zurcher (2008) had identified unemployment or underemployment issues such as low wages as well as fleeing war and/or civil unrest as push factors of brain drain. In addition, Kurka et al. (2008) in analyzing the brain drain of academics and researchers in Austria had cited the push factors such as: recommendations and experience of friends, improved opportunities for future career at home (foreign experience is valued) and escape from lack of career opportunities at home. Javed (2011) in his analysis on brain drain in developing countries cited: widespread unemployment/underemployment, low remunerations, low respect, less chances of professional or career development, poor general environment, poor living conditions (including education for children, health facilities, law and order, reliable supply of electricity, gas etc.) as reasons professionals leave their motherland.

Based on the discussion the following proposition is proposed:

P1: The push factors will motivate the local talent to migrate to other countries.

\section{Implication}

For Malaysia to advance into the forefront of knowledge it demands creative, innovative and knowledgeable human resources. This means a drastic revisit for both public and private sector collaboration in building science and technology as well as intellectual capital in management and entrepreneurship. Through this study both sectors can learn something in regard to the 
behavior of local talents. Thus it will bring two advantages. First, it can solve the brain drain phenomenon. It is because according to our deputy Prime Minister, Datuk Abdullah, many local k-workers migrate to developed countries for many reasons. Each year millions of Ringgit Malaysia is lost through the migration of nearly 30,000 of our k-workers (Ramon, 2006). By conducting this study, we can get a clear picture of the aspirations and feelings of a sample of Malaysian local talents. Consequently, the finding can be used in future by the government to construct and implement a plan to retain our local human capital in Malaysia. Secondly, this study is able to provide the insight views for both the push and pull factors related to sustaining local human capital as well as understand the reason of working outside Malaysia.

In other words, through this study, we will have clear ideas of what to expect when it come to brain drain in the context of Malaysia. Ambiguous views regarding brain drain among Malaysians have resulted in losses for the company as well as for the country. For Malaysia, the k-economy offers unlimited opportunities to its people. However, Malaysia currently lacks some critical elements to support the k-economy. Among the weaknesses stated is the readiness of society. K-based economy needs skilled and knowledgeable workers to handle and educate us through the process of globalization and technology. Via this study we can know more about the push and pull factors and ultimately assist the government to design an effective strategy to sustain local talents.

\section{Conclusion}

Wong (2010) in her study on plugging the brain drain in Malaysia identified the following push factors: economic situation (financial markets, prices of goods, cost of living, and international competitiveness); political situation (government policy, opposition party, stability, and corruption); human rights and media freedom; crime rate; quality of education; and inter-racial harmony. Parkins (2011) had identified the major push factors that influence international migration or brain drain in Jamaica as: crime and violence, an unstable economy (poor employment opportunities, sluggish economic growth) as well as mismatch between an individual's skill set and suitable occupation (education-occupation factor). Besides, Iravani (2011) mentioned that the push factors of individuals with technical knowledge and skills include: conflict, lack of opportunities, political instability or health risk. He added that the push factors that drove highly skilled labour in India to migrate encompass educated unemployment, low salary level (in comparison to unskilled workers), lack of promotion opportunities and lack of meritocracy and cronyism.

The World Bank Report (2011) on Malaysian Economic Monitor highlighted several push factors of Malaysian skilled migration based on various interviews conducted in Malaysia, Singapore and United States. These include: less attractive salary/benefits than overseas after adjustment for cost of living; lack of career prospects/unavailability of opportunities in specific field; lack of access to high quality education; social injustice such as unequal access to scholarship and higher education especially among the younger population of non-bumiputra origin; and safety and security issues. In addition, the report also highlighted religious fractionalization at country of origin as a strong push factor in high-skill emigration 
among developing countries. Lastly, Foo (2011) conducted an online survey on the drivers of brain drain in Malaysia based on 194 Malaysians based overseas. The survey results indicated the leading push factors of brain drain in Malaysia are: sense of social injustice, followed by lack of general safety and security, unsure political situation in Malaysia and poor livability conditions in Malaysia.

\section{Acknowledgements}

This research was funded by a short-term research grant PMGT 304 / PMGT / 6311100 from Universiti Sains Malaysia.

\section{References}

Batista, C., Lacuesta, A., \& Vicentre, P.C. (2011). Testing the brain gain hypothesis: Micro evidence from Cape Verde. Journal of Development Economics.

Boslaugh, S., \& Walters, P. A. (2008). Statistics in a Nutshell. O’Reilly: California.

Chacko, E. (2007). From brain drain to brain gain: reverse migration to Bangalore and Hyderabad, India's globalizing high tech cities. GeoJournal, 68, 131-140. http://dx.doi.org/10.1007/s10708-007-9078-8

Foo, G. (2011). Quantifying the Malaysian brain drain and an investigation of its key determinant. Malaysian Journal of Economic Studies, 48(2), 93-116.

Glytsos, N. P. (2010). Theoretical consideration and empirical evidence of brain drain grounding the review of Albania's and Bulgaria's experience. International Migration, 48(3), 107-130. http://dx.doi.org/10.1111/j.1468-2435.2008.00505.x

Gungor, N. D., \& Tansel, A. (2006). Brain Drain from Turkey: An Investigation of Students’ Return Intentions. Discussion Paper No. 2287 Institute for the Study of Labor (IZA), Bonn.

Gupta, D., \& Tyagi, R. (2011). Models proposed by economists to analyze the migration of skilled labours from developing countries like India. Journal of Emerging Trends in Economics and Management Sciences, 2(5), 344-349.

Ho, Y. J., \& Tyson, A. D. (2011). Malaysian migration to Singapore: Pathways, mechanisms and status. Malaysian Journal of Economic Studies, 48(2), 131-145.

Hunger, U. (2002). The 'Brain Gain' Hypothesis: Third-world Elites in Industrialized Countries and Socioeconomic Development in their Home Country. Working Paper 47. The Center for Comparative Immigration Studies, University of California, San Diego.

Iravani, M. R. (2011). Brain drain problem: A review. International Journal of Business and Social Science, 2(15), 284-289.

Javed, I. S. (2011). Brain drain: Why people leave their motherland? Journal of Managerial Science, 5(1), 63-74.

Kurka, B., Trippl, M., \& Maier, G. (2008). Understanding Scientific Mobility: Characteristics, Location Decisions, and Knowledge Circulation. A Case Study of 
Internationally Mobile Austrian Scientists and Researchers. DYNREG Working Papers: Dynamic Regions in a Knowledge-driven Global Economy. Lessons and Policy Implications for the EU.

Lim, L. (2004). Malaysia boosts efforts to reverse brain drain. [Online] Available: www.scidev.net

Lowell, B. L., \& Findlay, A. (2001). Migration of Highly Skilled Persons from Developing Countries: Impact and Policy Resources. International Migration Branch. International Labour Office. Geneva.

Malhotra, K. (2009). Tenth Malaysia Plan Brain Gain Malaysia Programme Workshop: The Challenge of Converting Brain Drain into Brain Gain for Developing Countries. United Nations Development Programme.

Martin, P., \& Zurcher, G. (2008). Managing migration: The global challenge. Population Bulletin, 63(1), 1-19.

Mountford, A. (1997). Can a brain drain be good for growth in the source economy? Journal of Development Economics, 53(2), 287-303. http://dx.doi.org/10.1016/S0304-3878(97)00021-7

News Straits Times. (2010). It’s not just about the money. June 14.

Nurse, K. (2004). Diaspora, Migration and Development in the Americas. [Online] Available: http: //library.fes.de/pdf-files/id/ipg/200402nurse.pdf.

Parkins, N. C. (2011). Push and pull factors of migration. American Review of Political Economy, 8(2), 6-24.

Portes, A. (1976). Determinants of the brain drain. International Migration Review Nr., 4, 489-508. http://dx.doi.org/10.2307/2545081

Ravendran, A. (2008). Brain drain or global mobility? Accountants Today, January.

Sako, S. (2002). Brain drain and Africa’s development: A reflection. Africa Issues, 30(1), 25-30. http://dx.doi.org/10.2307/1167086

Starbizweek. (2011a). Migration of talent—how can Malaysia stem the tide. April 30.

Starbizweek. (2011b). The scramble of skills. February 12.

Starbizweek. (2011c). Can Malaysia reform fast enough to meet challenges. April 30.

Starbizweek. (2011d). The big picture on skilled labour market. April 30.

Starbizweek. (2011e). Blueprint needed. February 12.

Starbizweek. (2011f). Education and security among reasons. February 12.

Starbizweek. (2011g). Malaysia’s got talent. February 12.

Starbizweek. (2011h). The ‘vicious cycle’ of brain drain. April 30. 


\section{Macrothink}

Stark, O., Helmenstein, C., \& Prskawetz, A. (1997). A brain gain with a brain drain. Economics Letters, 55(2), 227-234. http://dx.doi.org/10.1016/S0165-1765(97)00085-2

Stewart, T. A. (2000). Is Job Reality Necessary? Fortune, 154.

Straubhaar, T., \& Wolburg, M. R. (1999). Brain drain and brain gain in Europe: An evaluation of the East European migration to Germany. Jahrbucher filr Nationalokonomie and Statistik, 218(5-6).

Strempel, R. (2003). Self-esteem and job satisfaction. The Journal of Social Psychology, 14, 236-250.

Sunbiz. (2013). Talent Corp and the Singapore Conundrum. September 17.

Tansel, A., \& Gungor, N. D. (2003). Brain drain from Turkey: Survey evidence of student non-return. Career Development International, 82-69. http://dx.doi.org/10.1108/13620430310465453

The Edge. (2008). Creating and retaining the best brains and human assets. February 25.

The World Bank Report. (2011). Malaysian Economic Monitor-Brain Drain (April).

Tung, R. L., \& Lazarova, M. (2006). Brain drain versus brain gain: An exploratory study of ex-host country nationals in Central and East Europe. The International Journal of Human Resource Management, 17(11), 1853-1872. http://dx.doi.org/10.1080/09585190600999992

Wong, E. (2010). Plugging the brain drain. [Online] Available: http://pluggingthebraindrain.wordpress.com/about/

Ziguras, C., \& Law, S. F. (2006). Recruiting international students as skilled migrants: the global 'skill race' as viewed from Australia and Malaysia. Globalisation Societies and Education, 4(1), 59-76. http://dx.doi.org/10.1080/14767720600555087

Zweig, D., Fung, C. S., \& Han, D. L. (2008). Redefining the brain drain: China's diaspora option” Science. Technology and Society, 13(1), 1-33. http://dx.doi.org/10.1177/097172180701300101

\section{Copyright Disclaimer}

Copyright for this article is retained by the author(s), with first publication rights granted to the journal.

This is an open-access article distributed under the terms and conditions of the Creative Commons Attribution license (http://creativecommons.org/licenses/by/3.0/). 